\title{
STATUT $^{1}$ \\ Światowej Organizacji Turystyki, SPORZĄDZONY W MEKSYKU W DNIU 27 WRZEŚNIA 1970 R. $^{2}$
}

\section{Utworzenie}

\section{Artykuł 1}

Zostaje niniejszym utworzona Światowa Organizacja Turystyki określana dalej jako „Organizacja”, która jest organizacją międzynarodową o charakterze międzyrządowym, powstałą z przekształcenia Międzynarodowego Związku Oficjalnych Organizacji Turystycznych.

\section{Siedziba}

\section{Artykuł 2}

Siedziba Organizacji zostanie wyznaczona i w dowolnym czasie może zostać zmieniona, na mocy decyzji Zgromadzenia Ogólnego.

${ }^{1}$ Materiał źródłowy został opracowany w ramach międzyuczelnianej współpracy pomiędzy Katedrą Prawa Międzynarodowego i Amerykańskiego Katolickiego Uniwersytetu Lubelskiego Jana Pawła II, Katedrą Prawa Międzynarodowego Publicznego Uniwersytetu Marii Curie-Skłodowskiej w Lublinie, Katedrą Prawa Międzynarodowego Uniwersytetu Szczecińskiego oraz Katedrą Prawa Międzynarodowego Publicznego i Prawa Europejskiego Uniwersytetu Śląskiego w Katowicach.

2 Statutes of the World Tourism Organizaton adopted by the Extraordinary General Assembly of International Union of Official Travel Organisations (IUOTO) held at Mexico City, from 17 to 28 September 1970. Tekst Statutu w języku angielskim został opublikowany w: UNWTO Basic Documents, Volume I - Statutes, Rules of Procedure, Agreements, Fifth edition - Updated and revised, UNWTO, Madrid 2016, s. 15-42. Statut wszedł w życie w dniu 2 stycznia $1975 \mathrm{r}$. 


\section{Cele}

\section{Artykuł 3}

1. Zasadniczym celem Organizacji jest popieranie i rozwój turystyki, mający przyczyniać się do rozwoju gospodarczego, międzynarodowego zrozumienia, pokoju, dobrobytu oraz powszechnego poszanowania i przestrzegania praw człowieka i podstawowych wolności dla wszystkich, bez względu na różnicę rasy, płci, języka lub wyznania. Organizacja podejmie wszelkie właściwe działania dla osiągnięcia tego celu.

2. Realizując ten cel, Organizacja będzie zwracać szczególną uwagę na interesy krajów rozwijających się w dziedzinie turystyki.

3. Dla zapewnienia swej centralnej roli w dziedzinie turystyki Organizacja nawiąże i będzie utrzymywała efektywną współpracę z właściwymi organami Organizacji Narodów Zjednoczonych i jej organizacjami wyspecjalizowanymi. W związku z tym Organizacja będzie zmierzała do ustanowienia stosunków współpracy i uczestnictwa w działalności Programu Rozwojowego Narodów Zjednoczonych, jako agencja uczestnicząca w Programie i jego wykonawca.

\section{Członkostwo}

Artykuł 4

Członkostwo w Organizacji jest otwarte dla:

a) członków pełnoprawnych,

b) członków stowarzyszonych,

c) członków afiliowanych.

\section{Artykuł 5}

1. Status członka pełnoprawnego Organizacji jest dostępny dla wszystkich suwerennych państw.

2. Państwa, których krajowe organizacje turystyczne są członkami pełnoprawnymi IUOTO w czasie przyjęcia niniejszego Statutu przez Nadzwyczajne Zgromadzenie Ogólne IUOTO, będą miały prawo stać się członkami pełnoprawnymi Organizacji, bez wymogu głosowania, po złożeniu formalnej deklaracji o przyjęciu Statutu Organizacji i zaakceptowaniu zobowiązań członkowskich.

3. Inne państwa mogą stać się członkami pełnoprawnymi Organizacji, jeżeli ich kandydatury zostaną zatwierdzone przez Zgromadzenie Ogólne większością dwóch trzecich głosów członków pełnoprawnych obecnych i głosujących pod warunkiem, że na powyższą większość składa się większość członków pełnoprawnych. 


\section{Artykuł 6}

1. Status członka stowarzyszonego Organizacji jest dostępny dla wszystkich terytoriów lub grup terytoriów nieponoszących odpowiedzialności za swe stosunki zewnętrzne.

2. Terytoria lub grupy terytoriów, których krajowe organizacje turystyczne są członkami pełnoprawnymi IUOTO w czasie przyjęcia niniejszego Statutu przez Nadzwyczajne Zgromadzenie Ogólne IUOTO, mają prawo stać się członkami stowarzyszonymi Organizacji, bez wymogu głosowania pod warunkiem, że państwo ponoszące odpowiedzialność za ich stosunki zewnętrzne zaaprobuje ich członkostwo i oświadczy w ich imieniu, że takie terytoria lub grupy terytoriów przyjmują Statut Organizacji i akceptują zobowiązania członkowskie.

3. Terytoria lub grupy terytoriów mogą stać się członkami stowarzyszonymi Organizacji, jeżeli państwo członkowskie ponoszące odpowiedzialność za ich stosunki zewnętrzne uprzednio zaaprobuje ich kandydatury i oświadczy w ich imieniu, że takie terytoria lub grupy terytoriów przyjmują Statut Organizacji i akceptują zobowiązania członkowskie. Tego rodzaju kandydatury muszą być zatwierdzone przez Zgromadzenie większością dwóch trzecich głosów członków pełnoprawnych obecnych i głosujących pod warunkiem, że na powyższą większość składa się większość członków pełnoprawnych.

4. Gdy członek stowarzyszony Organizacji przejmie odpowiedzialność za prowadzenie swych stosunków zewnętrznych, staje się uprawniony do uzyskania pełnoprawnego członkostwa Organizacji po złożeniu Sekretarzowi Generalnemu formalnej deklaracji pisemnej o przyjęciu Statutu Organizacji i zaakceptowaniu zobowiązań wynikających z pełnoprawnego członkostwa.

\section{Artykuł 7}

1. Status członka afiliowanego Organizacji jest dostępny dla międzynarodowych organizacji, zarówno międzyrządowych, jak i pozarządowych, zajmujących się wyspecjalizowanymi problemami turystyki, oraz dla organizacji handlowych i stowarzyszeń, których działalność ma związek z celami Organizacji lub wchodzi w zakres jej kompetencji.

2. Członkowie stowarzyszeni IUOTO, w czasie przyjęcia niniejszego Statut przez Nadzwyczajne Zgromadzenie Ogólne IUOTO, mają prawo stać się członkami afiliowanymi Organizacji, bez wymogu głosowania, po złożeniu deklaracji o zaakceptowaniu zobowiązań wynikających z członkostwa afiliowanego.

3. Inne organizacje międzynarodowe, zarówno międzyrządowe, jak i pozarządowe, zajmujące się wyspecjalizowanymi problemami turystyki, mogą stać się członkami afiliowanymi Organizacji - jeżeli ich wniosek o przyjęcie złożony w formie pisemnej Sekretarzowi Generalnemu uzyska aprobatę Zgromadzenia większością dwóch trzecich głosów członków pełnoprawnych 
obecnych i głosujących pod warunkiem, że na powyższą większość składa się większość członków pełnoprawnych.

4. Organizacje handlowe lub stowarzyszenia o profilu działania określonym w paragrafie 1 mogą stać się członkami afiliowanymi Organizacji pod warunkiem, że ich wnioski o przyjęcie, poparte przez państwo, w którym mieści się siedziba kandydata, zostaną w formie pisemnej przedłożone Sekretarzowi Generalnemu. Tego rodzaju kandydatury muszą być zatwierdzone przez Zgromadzenie większością dwóch trzecich głosów członków pełnoprawnych obecnych i głosujących pod warunkiem, że na powyższą większość składa się większość członków pełnoprawnych.

5. Może zostać utworzony Komitet Członków Afiliowanych, który ustali swój regulamin przedłożony następnie do zatwierdzenia Zgromadzeniu. Komitet może być reprezentowany na zebraniach organizacji. Może występować z wnioskiem o wpisanie różnych problemów do porządku dziennego tych zebrań. Może również formułować zalecenia dla zebrań.

6. Członkowie afiliowani mogą uczestniczyć w działalności Organizacji indywidualnie lub grupowo w Komitecie Członków Afiliowanych.

\section{Organy}

Artykuł 8

1. Organami Organizacji są:

a) Zgromadzenie Ogólne, określane dalej jako Zgromadzenie,

b) Rada Wykonawcza, określana dalej jako Rada,

c) Sekretariat.

2. Zebrania Zgromadzenia i Rady będą odbywały się w siedzibie Organizacji, o ile odpowiedni organ nie ustali inaczej.

\section{Zgromadzenie Ogólne}

\section{Artykuł 9}

1. Zgromadzenie jest najwyższym organem Organizacji i składa się z delegatów reprezentujących członków pełnoprawnych.

2. Podczas każdej sesji Zgromadzenia każdy członek pełnoprawny i stowarzyszony jest reprezentowany przez nie więcej niż pięciu delegatów, z których jeden jest wyznaczony przez Członka jako szef delegacji.

3. Komitet Członków Afiliowanych może wyznaczyć nie więcej niż trzech obserwatorów, a każdy członek afiliowany jednego obserwatora, którzy mogą uczestniczyć w pracach Zgromadzenia. 


\section{Artykuł 10}

Zgromadzenie zbiera się co dwa lata na sesję zwyczajną, a gdy tego będą wymagały okoliczności, również na sesję nadzwyczajną. Sesje nadzwyczajne mogą być zwoływane na wniosek Rady lub większości członków pełnoprawnych Organizacji.

\section{Artykuł 11}

Zgromadzenie zatwierdza swój regulamin.

\section{Artykuł 12}

Zgromadzenie może rozpatrywać wszelkie zagadnienia i formułować zalecenia we wszystkich sprawach wchodzących w zakres kompetencji Organizacji. Do funkcji Zgromadzenia, poza innymi przyznanymi mu w niniejszym Statucie, należą:

a) dokonywanie wyboru swego przewodniczącego i jego zastępców,

b) dokonywanie wyboru członków Rady,

c) mianowanie Sekretarza Generalnego na zalecenie Rady,

d) zatwierdzanie regulaminu finansowego Organizacji,

e) określanie głównych wytycznych dla zarządzania Organizacją,

f) zatwierdzanie regulaminu osobowego dotyczącego personelu Sekretariatu,

g) dokonywanie wyboru komisarzy finansowych na zalecenie Rady,

h) zatwierdzanie ogólnego programu pracy Organizacji,

i) nadzorowanie polityki finansowej Organizacji, rozpatrywanie i zatwierdzanie jej budżetu,

j) w razie potrzeby - tworzenie organów technicznych lub regionalnych,

k) rozpatrywanie i zatwierdzanie sprawozdań z działalności Organizacji i jej organów oraz podejmowanie wszelkich niezbędnych kroków dla realizowania wypływających z nich wniosków,

1) wyrażanie zgody lub przekazywanie kompetencji do wyrażania zgody na zawarcie porozumień z rządami lub organizacjami międzynarodowymi,

m) wyrażanie zgody lub przekazywanie kompetencji do wyrażenia zgody na zawarcie porozumień z prywatnymi organizacjami lub instytucjami prywatnymi,

n) przygotowywanie i zalecanie zawarcia porozumień międzynarodowych odnośnie do wszelkich zagadnień wchodzących w zakres kompetencji Organizacji,

o) podejmowanie decyzji zgodnie z niniejszym Statutem dotyczących podań o przyjęcie w poczet członków. 
Artykuł 13

1. Na początku każdej sesji Zgromadzenie wybiera swego przewodniczącego i jego zastępców.

2. Przewodniczący kieruje pracami Zgromadzenia i wypełnia obowiązki, które zostały mu powierzone.

3. Podczas trwania sesji przewodniczący jest odpowiedzialny przed Zgromadzeniem.

4. Przewodniczący reprezentuje Organizację w okresie swej kadencji przy wszystkich okazjach wymagających tego rodzaju reprezentacji.

\section{Rada Wykonawcza}

Artykuł 14

1. Rada składa się z członków pełnoprawnych wybieranych przez Zgromadzenie w stosunku jeden członek Rady na każdych pięciu członków pełnoprawnych, zgodnie z zasadami proceduralnymi ustalonymi przez Zgromadzenie, mając na uwadze zachowanie zasady sprawiedliwego i równego podziału geograficznego.

2. Jeden z członków stowarzyszonych, wybrany przez członków stowarzyszonych Organizacji, może brać udział w pracach Rady bez prawa do głosowania.

3. Przedstawiciel Komitetu Członków Afiliowanych może brać udział w pracach Rady bez prawa do głosowania.

Artykuł 15

Kadencja wybranych członków trwa cztery lata, z wyjątkiem kadencji połowy członków pierwszej Rady, wybranych w drodze losowania, która trwa dwa lata. Wybory połowy składu Rady będą odbywały się co dwa lata.

Artykuł 16

Rada zbiera się co najmniej dwa razy w roku.

Artykuł 17

Rada wybiera spośród swoich wybranych członków przewodniczącego i wiceprzewodniczącego do pełnienia obowiązków przez rok.

Artykuł 18

Rada uchwala swój regulamin. 


\section{Artykuł 19}

Do funkcji Rady, poza innymi przyznanymi jej w niniejszym Statucie, należy:

a) podejmowanie niezbędnych kroków, w konsultacji z Sekretarzem Generalnym, dla wykonywania decyzji i zaleceń Zgromadzenia i zdawanie sprawozdań Zgromadzeniu,

b) przyjmowanie sprawozdań Sekretarza Generalnego o działalności Organizacji,

c) przedkładanie propozycji Zgromadzeniu,

d) rozpatrywanie ogólnego programu działalności Organizacji, przygotowywanego przez Sekretarza Generalnego, przed przedłożeniem go Zgromadzeniu,

e) przedkładanie Zgromadzeniu sprawozdań i zaleceń w sprawach finansowych oraz planów budżetowych Organizacji,

f) ustanawianie wszelkich organów pomocniczych, które mogą być niezbędne dla jej działalności,

g) wykonywanie wszelkich innych funkcji powierzonych jej przez Zgromadzenie.

Artykuł 20

W okresie między dwiema sesjami Zgromadzenia, jeżeli przepisy niniejszego Statusu nie stanowią inaczej, Rada podejmuje niezbędne decyzje o charakterze administracyjnym i technicznym, w ramach uprawnień i możliwości finansowych Organizacji oraz na kolejnym posiedzeniu Zgromadzenia Rada informuje Zgromadzenie o podjętych decyzjach w celu ich zatwierdzenia.

\section{Sekretariat}

Artykuł 21

Sekretariat składa się z Sekretarza Generalnego i personelu, jaki może być Organizacji potrzebny.

Artykuł 22

Sekretarz Generalny jest mianowany na cztery lata, na zalecenie Rady, większością dwóch trzecich głosów członków pełnoprawnych obecnych i głosujących na Zgromadzeniu. Mianowanie może być odnawialne.

Artykuł 23

1. Sekretarz Generalny jest odpowiedzialny przed Zgromadzeniem i Radą. 
2. Sekretarz Generalny działa zgodnie z wytycznymi Zgromadzenia i Rady. Przedkłada Radzie sprawozdania z działalności Organizacji, rozliczenia finansowe, projekty ogólnego programu pracy i budżetu Organizacji.

3. Sekretarz zapewnia prawną reprezentację Organizacji.

Artykuł 24

1. Sekretarz Generalny mianuje personel Sekretariatu zgodnie z regulaminem osobowym zatwierdzonym przez Zgromadzenie.

2. Personel Organizacji jest odpowiedzialny przed Sekretarzem Generalnym.

3. Przy mianowaniu personelu i ustalaniu warunków służby należy przede wszystkim liczyć się z koniecznością zapewnienia najwyższego poziomu sprawności, kwalifikacji zawodowych i uczciwości. Mając to na uwadze, trzeba również w należytym stopniu uwzględnić znaczenie doboru personelu na możliwie najszerszej podstawie geograficznej.

4. W wykonywaniu swych obowiązków Sekretarz Generalny i personel nie ubiegają się i nie przyjmują żadnych instrukcji od jakiegokolwiek rządu lub władzy pozostającej poza Organizacją. Powstrzymują się od wszelkich działań niezgodnych $\mathrm{z}$ ich statusem funkcjonariuszy międzynarodowych odpowiedzialnych tylko przed Organizacją.

\section{Budżet i wydatki}

Artykuł 25

1. Budżet Organizacji, obejmujący jej działalność administracyjną i ogólny program prac, jest finansowany ze składek członków pełnoprawnych, stowarzyszonych i afiliowanych zgodnie ze skalą ich wymiaru przyjętą przez Zgromadzenie, jak również z innych możliwych źródeł wpływów Organizacji, zgodnie $\mathrm{z}$ regulaminem finansowym załączonym do niniejszego Statutu i stanowiącym jego integralną część.

2. Budżet sporządzany przez Sekretarza Generalnego jest przedkładany przez Radę do rozpatrzenia i zatwierdzenia przez Zgromadzenie.

\section{Artykuł 26}

1. Finanse Organizacji są badane przez dwóch komisarzy finansowych wybieranych przez Zgromadzenie, na zalecenie Rady, na dwa lata, z możliwością ponownego wyboru.

2. Komisarze finansowi, poza kontrolą finansową, mogą wnosić wszelkie uwagi, jakie uważają za niezbędne, dotyczące efektywności procedur finansowych i zarządzania, systemu rozliczeń finansowych, wewnętrznych kontroli finansowych, jak również, w ogólności, wszelkich finansowych konsekwencji wynikających z praktyk administracyjnych. 


\section{Kworum}

\section{Artykuł 27}

1. Obecność większości członków pełnoprawnych jest konieczna do zapewnienia kworum na posiedzeniach Zgromadzenia.

2. Obecność większości członków pełnoprawnych wchodzących w skład Rady jest konieczna do zapewnienia kworum na posiedzeniach Rady.

\section{Głosowanie}

Artykuł 28

Każdy członek pełnoprawny dysponuje jednym głosem.

\section{Artykuł 29}

1. Jeśli niniejszy Statut nie stanowi inaczej, decyzje we wszystkich sprawach są podejmowane przez Zgromadzenie zwykłą większością głosów członków pełnoprawnych obecnych i głosujących.

2. Większość dwóch trzecich głosów członków pełnoprawnych obecnych i głosujących jest wymagana do podjęcia decyzji w sprawach pociągających za sobą zobowiązania budżetowe i finansowe członków, w sprawie miejsca siedziby Organizacji, jak również w odniesieniu do innych zagadnień uznanych za szczególnie ważne przez zwykłą większość członków pełnoprawnych obecnych i głosujących w Zgromadzeniu.

\section{Artykuł 30}

Decyzje Rady są podejmowane zwykłą większością członków obecnych i głosujących, z wyjątkiem zaleceń w sprawach budżetowych i finansowych, które są zatwierdzane większością dwóch trzecich członków obecnych i głosujących.

\section{Osobowość prawna, przywileje i immunitety}

\section{Artykuł 31}

Organizacja ma osobowość prawną.

\section{Artykuł 32}

Organizacja korzysta na terytorium państw członkowskich z przywilejów i immunitetów niezbędnych do wykonywania swych funkcji. Tego rodzaju przy wileje i immunitety mogą zostać określone w porozumieniach zawieranych przez Organizację. 


\section{Zmiany Statutu}

\section{Artykuł 33}

1. Każdy projekt zmiany niniejszego Statutu i jego załączników jest przekazywany Sekretarzowi Generalnemu, który poinformuje o tym członków pełnoprawnych co najmniej na sześć miesięcy przed przekazaniem go do rozpatrzenia przez Zgromadzenie.

2. Zmiany są uchwalane przez Zgromadzenie większością dwóch trzecich głosów członków pełnoprawnych obecnych i głosujących.

3. Zmiany niniejszego Statutu uzyskują moc prawną w stosunku do wszystkich członków, jeżeli dwie trzecie państw członkowskich powiadomi rząd będący depozytariuszem niniejszego Statutu o zatwierdzeniu tego rodzaju zmiany.

\section{Zawieszenie członkostwa}

\section{Artykuł 34}

1. Jeżeli Zgromadzenia stwierdzi, że członek Organizacji uporczywie prowadzi politykę sprzeczną z podstawowym celem Organizacji wymienionym $\mathrm{w}$ artykule 3 niniejszego Statutu, może ono na mocy rezolucji przyjętej większością dwóch trzecich głosów członków pełnoprawnych obecnych i głosujących zawiesić takiego członka w wykonywaniu praw i korzystaniu z przywilejów członkowskich.

2. Zawieszenie w prawach członkowskich pozostaje w mocy do czasu stwierdzenia przez Zgromadzenie zmiany tego rodzaju polityki.

\section{Wystąpienie}

Artykuł 35

1. Każdy członek pełnoprawny może wystąpić z Organizacji po upływie roku od przekazania pisemnego zawiadomienia skierowanego do rządu będącego depozytariuszem.

2. Każdy członek stowarzyszony może wystąpić z Organizacji, przy zachowaniu tych samych zasad powiadomienia, pod warunkiem, że rząd będący depozytariuszem został o tym pisemnie zawiadomiony przez członka pełnoprawnego, który ponosi odpowiedzialność za stosunki zewnętrzne tego członka stowarzyszonego.

3. Członek afiliowany może wystąpić z Organizacji po upływie roku od przekazania pisemnego zawiadomienia skierowanego do Sekretarza Generalnego. 


\section{Wejście w życie}

\section{Artykuł 36}

Niniejszy Statut wchodzi w życie po upływie stu dwudziestu dni od formalnego powiadomienia tymczasowego depozytariusza przez pięćdziesiąt jeden państw, których oficjalne organizacje turystyczne są członkami pełnoprawnymi IUOTO w chwili przyjęcia niniejszego Statutu, o zaakceptowaniu Statutu i przyjęciu zobowiązań wynikających z członkostwa.

\section{Depozytariusz}

\section{Artykuł 37}

1. Niniejszy Statut i wszelkie deklaracje o przyjęciu zobowiązań członkowskich będą tymczasowo złożone do depozytu rządowi Szwajcarii.

2. Rząd Szwajcarii powiadomi wszystkie państwa, które mają prawo do otrzymania tego rodzaju notyfikacji, o otrzymaniu takich deklaracji oraz o dacie wejścia w życie niniejszego Statutu.

\section{Języki i tłumaczenia}

Artykuł 38

Oficjalnymi językami Organizacji są języki: angielski, arabski, francuski, rosyjski i hiszpański.

\section{Artykuł 39}

Teksty w języku angielskim, francuskim, rosyjskim i hiszpańskim niniejszego Statutu są uznawane za jednakowo autentyczne.

\section{Postanowienia przejściowe}

Artykuł 40

Zgodnie z artykułem 2 na mocy decyzji Zgromadzenia Ogólnego siedzibą Organizacji będzie tymczasowo Genewa (Szwajcaria).

\section{Artykuł 41}

W okresie 180 dni od dnia wejścia w życie niniejszego Statutu Państwa Członkowskie Organizacji Narodów Zjednoczonych, organizacji wyspecjalizowanych i Międzynarodowej Agencji Energii Atomowej oraz strony Statutu Międzynarodowego Trybunału Sprawiedliwości mają prawo stać się człon- 
kami pełnoprawnymi Organizacji, bez wymogu głosowania, po formalnym złożeniu deklaracji o przyjęciu Statutu Organizacji i zaakceptowaniu zobowiązań członkowskich.

\section{Artykuł 42}

W okresie jednego roku od wejścia w życie obecnego Statutu państwa, których krajowe organizacje turystyczne były członkami pełnoprawnymi IUOTO w chwili przyjęcia niniejszego Statutu i które przyjęły obecny Statut pod warunkiem potwierdzenia, mogą uczestniczyć w działalności Organizacji z zachowaniem praw i zobowiązań członków pełnoprawnych.

\section{Artykuł 43}

W okresie jednego roku od wejścia w życie obecnego Statutu terytoria lub grupy terytoriów nieponoszące odpowiedzialności za prowadzenie swych stosunków zewnętrznych, lecz których organizacje turystyczne były członkami pełnoprawnymi IUOTO, co upoważniało je do statusu członka stowarzyszonego i które jednocześnie przyjęły niniejszy Statut pod warunkiem potwierdzenia przez państwo ponoszące odpowiedzialność za ich stosunki zewnętrzne, mogą uczestniczyć w działalności Organizacji z zachowaniem praw i zobowiązań członków stowarzyszonych.

Artykuł 44

W chwili gdy obecny Statut wejdzie w życie, prawa i zobowiązania IUOTO zostaną przeniesione na Organizację.

Artykuł 45

W chwili wejścia w życie niniejszego Statutu Sekretarz Generalny IUOTO rozpocznie działalność jako Sekretarz Generalny Organizacji - do czasu wybrania przez Zgromadzenie Sekretarza Generalnego Organizacji.

Sporządzono w Meksyku w dniu 27 września 1970 r.

\section{Załącznik 1}

\section{REGULAMIN FINANSOWY}

1. Okres budżetowy Organizacji trwa dwa lata.

2. Rok budżetowy obejmuje okres od 1 stycznia do 31 grudnia.

3. Budżet jest finansowany ze składek członkowskich zgodnie z metoda przedzielenia określoną przez Zgromadzenie, na podstawie poziomu rozwoju gospodarczego i znaczenia turystyki w każdym kraju oraz z innych dochodów Organizacji. 
4. Budżet jest określany w dolarach amerykańskich. Walutą, w której dokonuje się płatności składek, są dolary amerykańskie. Nie wyklucza to możliwości zaakceptowania przez Sekretarza Generalnego innych walut $\mathrm{w}$ zakresie, $\mathrm{w}$ jakim jest on do tego upoważniony przez Zgromadzenie, dla dokonywania płatności z tytułu składek członkowskich.

5. Tworzy się Fundusz Ogólny. Wszystkie składki członkowskie wpłacane zgodnie z paragrafem 3, różne dochody i wszelkie zaliczki z Funduszu Obrotowego będą uznawane w Funduszu Ogólnym. Wydatki na administrację i realizację programu ogólnego będą wypłacane z Funduszu Ogólnego.

6. Tworzy się Fundusz Obrotowy, którego wysokość ustala Zgromadzenie. Zaliczki na poczet składek członkowskich i wszelkie inne wpływy budżetowe, o których wykorzystaniu decyduje Zgromadzenie, są wpłacane na Fundusz Obrotowy. Gdy zajdzie potrzeba, sumy z Funduszu Obrotowego będą przelewane na Fundusz Ogólny.

7. Dla finansowania działalności nieprzewidzianej w budżecie Organizacji, którą są zainteresowane niektóre państwa członkowskie lub grupy państw, mogą być utworzone fundusze gwarancyjne. Tego rodzaju fundusze będą finansowane z wkładów dobrowolnych. Organizacja ma prawo do pobierania opłat za administrowanie tego rodzaju funduszami.

8. O wykorzystaniu darowizn, zapisów i innych dochodów nadzwyczajnych nieobjętych budżetem decyduje Zgromadzenie.

9. Sekretarz Generalny przedkłada projekty budżetu Radzie co najmniej na trzy miesiące przed odpowiednim posiedzeniem Rady. Rada rozpatruje powyższy projekt i przedkłada budżet Zgromadzeniu do ostatecznego rozpatrzenia i zatwierdzenia. Projekty budżetu rozpatrzone przez Radę przesyłane są członkom co najmniej na trzy miesiące przed właściwą sesją Zgromadzenia.

10. Zgromadzenie zatwierdza budżet na każdy rok objęty dwuletnim okresem finansowym oraz jego coroczny rozdział, jak również koszty administracyjne na każdy rok.

11. Sekretarz Generalny przekazuje zestawienie wydatków Organizacji $\mathrm{z}$ ostatniego roku finansowego komisarzom finansowym i właściwemu organowi Rady.

Komisarze finansowi składają sprawozdanie Radzie i Zgromadzeniu.

12. Członkowie Organizacji wpłacają przypadające na nich składki w pierwszym miesiącu roku budżetowego, za który składka jest należna. Wysokość tej należności ustalana przez Zgromadzenie będzie podawana do wiadomości członków na sześć miesięcy przed rozpoczęciem roku budżetowego, którego dotyczy.

Rada może jednak uznać uzasadnione przypadki zwłoki w opłacaniu należnych składek wynikłe $\mathrm{z}$ różnic $\mathrm{w}$ ujmowaniu lat budżetowych $\mathrm{w}$ poszczególnych państwach. 
13. Członek, który zalega w opłacaniu składek, z których pokrywane są wydatki Organizacji, nie będzie mógł korzystać z przywilejów udzielanych $\mathrm{w}$ formie świadczeń ani z prawa głosu na Zgromadzeniu i Radzie, jeżeli suma zaległych świadczeń na rzecz Organizacji jest równa lub przekracza należne kwoty z tytułu składek za okres dwóch lat budżetowych.

Na wniosek Rady Zgromadzenie może zezwolić takiemu członkowi na udział w głosowaniu i korzystanie ze świadczeń Organizacji, jeżeli uzna, że zaległość wynikła z przyczyn niezależnych od członka.

14. Członek występujący z Organizacji jest zobowiązany do opłacania należnej części składek do czasu efektywnego ustania członkostwa.

15. Przy ustalaniu składek członków stowarzyszonych i afiliowanych będzie brany pod uwagę ich różny status członkowski i ograniczone prawa, z jakich korzystają w Organizacji.

Niniejszy Regulamin Finansowy nabiera mocy wraz z wejściem w życie Statutu Organizacji, stanowiąc jego integralną część. Zmiany Regulaminu mogą być dokonywane zgodnie $\mathrm{z}$ artykułem 30 Statutu.

Sporządzono w Meksyku w dniu 27 września 1970 r.

tłum. Anna Przyborowska-Klimczak*

* Prof. dr hab., Uniwersytet Marii Curie-Skłodowskiej w Lublinie. 